Published by Al-Nahrain College of Medicine P-ISSN 1681-6579

E-ISSN 2224-4719

Email: iraqijms@colmed-alnahrain.edu.iq

http://www.colmed-alnahrain.edu.iq

http://www.iraqijms.net

Iraqi JMS 2020; Vol. 18(2)

\title{
Is Sublay Mesh Repair for Incisional Hernia Better Than Conventional Onlay Mesh Repair?
}

\author{
Yasir A. Hasan ${ }^{1}$ FICMS, Sajid H.A. Al-Helfy ${ }^{2} C A B S$, FICMS, Riaydh T. Jabur ${ }^{3}$ FICMS \\ ${ }^{1} \mathrm{Al}-$ Hakeem general hospital, Baghdad, Iraq, ${ }^{2}$ Dept. of Surgery, College of Medicine, Al-Nahrain University, Baghdad, \\ Iraq, Al-Imamein Al-Kadhimein Medical City, Baghdad, Iraq
}

\begin{abstract}
Background Incisional hernia $(\mathrm{IH})$ after abdominal surgery is a well-known complication and its incidence continues to be $10-15 \%$ after laparotomy. The repair of $\mathrm{IH}$ has always been a challenge to the surgeon. Various operative techniques for the repair of $\mathrm{IH}$ are in practice; however, the management is not standardized. The sublay technique has been reported to be quite effective, with low recurrence rates and minimal complications.

Objective To assess the advantage and complications of sublay mesh repair of $\mathrm{IH}$ in comparison to onlay mesh repair.

Methods Prospective study of 63 patients undergoing repair of $\mathrm{IH}$ from $1^{\text {st }}$ January 2013 to $1^{\text {st }}$ February 2015 done in General Surgical Unit of Al-Imamein Al-kadhmein Medical City. 42 cases of IH were managed by onlay mesh repair and 21 cases of $\mathrm{IH}$ were managed by sublay mesh repair.

Results Post-operative complications like seroma and wound infection were comparable in both groups. In sublay group seroma formation was one patient $(4.76 \%)$. Wound infection was in one patient (4.76\%). No septic mesh was removed in the series. In onlay group, seroma formation was in 9 patients (21.42\%); most of seroma occur in large $\mathrm{IH}$ repair, wound infection was in 2 patients $(4.76 \%)$ and one septic mesh was removed. In sublay recurrence rate was $0 \%$, in onlay recurrence rate was in one patient (4.76\%).

Conclusion Sublay mesh although it is more time consuming and technically more difficult, however, it carries low recurrence rate and few postoperative wound complication.

Keywords Sublay, onlay, Mesh Repair, Incisional Hernia

Citation

Hasan YA, Al-Helfy SHA, Jabur RT. Is sublay mesh repair for incisional hernia better than conventional onlay mesh repair? Iraqi JMS. 2020; 18(2): 138-144. doi: 10.22578/JJMS.18.2.8.
\end{abstract}

List of abbreviations: IH = Incisional hernia, $\mathrm{IPOM}=$ Intraperitoneal onlay mesh, $\mathrm{PUH}=$ Paraumbilical hernia

\section{Introduction}

$\mathrm{T}$ The hernias and its treatment has fascinated surgeons of all latitudes throughout the years of recorded medical history, the operation for the hernia have been paramount indicator of the progress of surgical technique itself. William S. Halstead of the Johns Hopkins School of Medicine said in 1892 that "there is, perhaps, no operation which, by the profession at large, would be more appreciated than a perfectly safe cure for rupture "(1).

Incisional hernias $(\mathrm{IH})$, by definition, develop at sites where an incision has been made for some prior abdominal procedure. Hernias are due to failure of fascial tissues to heal and close following laparotomy. Any condition that inhibits natural wound healing will make a patient susceptible to the development of an $\mathrm{IH}$; such conditions include: infection, obesity, smoking, medications such as 
immunosuppressive, excessive wound tension, malnutrition, fractured sutures, poor technique, and connective tissue disorders ${ }^{(2)}$. Emergency surgery increases the risk of IH formation. It is estimated that an IH develop in approximately $10-15 \%$ of abdominal incisions ${ }^{(2,3)}$ and in up to $23 \%$ of patients who develop postoperative wound infection ${ }^{(4)}$.

Such hernias can occur after any type of abdominal wall incision, although the highest incidence is seen with midline incisions, the most common incisions for many abdominal procedures ${ }^{(4)}$. Even the smallest $\mathrm{IH}$ has the potential for incarceration and, therefore, repair should be considered. Hernias that are less likely to incarcerate include upper abdominal hernias, hernias less than $1 \mathrm{~cm}$ in diameter, and unilocular diffuse hernias larger than 7 to $8 \mathrm{~cm}$ (where loops of bowel can move in and out of the hernia sac without restriction, and are therefore less likely to become Incarcerated) (5).

As a result of high recurrence rate in the repair of $\mathrm{IH}$, various types of repairs have been used both anatomical and prosthetic. But the results have been disappointing with a high incidence of recurrence of about $30-50 \%$ after anatomical primary tissue repair and $1.5-10 \%$ following prosthetic mesh repairs. The introduction of prosthetics had been revolutionized hernia surgery with the concept of tension free repair (5).

Although a wide variety of surgical procedures have been adopted for the repair of $\mathrm{IH}$, but the implantation of prosthetic mesh remains the most efficient method of dealing with $\mathrm{IH}^{(6)}$, and the advantage is to reduce recurrence rate in $\mathrm{IH}$ (7). Albeit it was associated with complications like infection, seroma, variable recurrence rate, and a limited use in contaminated hernia ${ }^{(8)}$.

The prosthetic mesh can be placed in just outside of the muscle in the subcutaneous space (onlay); within the defect (inlay) only applies to mesh plugs in small defect; between fascial layers in the abdominal wall (intraparietal or sublay); immediately extraperitoneally, retro muscular against muscle or fascia (also sublay); intraperitoneal onlay mesh (IPOM) ${ }^{(9,10)}$.

The sublay are preferred as it reduces the recurrence rate by allowing larger pieces of prosthetic material to be used and incorporating intra-abdominal pressure to aid in keeping the mesh in place ${ }^{(10)}$.

The sublay mesh hernia repair was first described by Stoppa ${ }^{(10)}$, Rives ${ }^{(11)}$ and Wantz ${ }^{(12)}$. This technique is considered by many surgeons to be the gold standard for the open repair of abdominal IH ${ }^{\left(1{ }^{-17)}\right.}$ (sublay mesh repair).

Surgical techniques for the repair of $\mathrm{IH}$ continued to evolve with advances in prosthetic materials while the primary tissue repair was associated with higher unacceptable recurrence rate. Nowadays tension free mesh repair is ideal hernia repair technique ${ }^{(18)}$.

However, the optimal technique for mesh placement has not been established and remains controversial. The prosthetic mesh can be placed between the subcutaneous tissues of the abdominal wall and the anterior rectus sheath (onlay mesh repair) as well as in the preperitoneal (sublay mesh repair). The latter technique has several advantages one of being not transmitting the infection from subcutaneous tissues down to the mesh as it lies quite (19).

Increased intra-abdominal pressure acting anteriorly on the margins tends to oppose the mesh to the abdominal wall rather than distracting it.

This study was conducted in our center to evaluate applicability of sublay mesh repair and their outcome in comparison to traditional onlay mesh repair in patient with incisional hernia.

The aim of the study was to evaluate the technique and complications of sublay mesh repair of incisional hernias in comparison with onlay mesh repair.

\section{Methods}

This prospective comparative study was carried out on 63 patients of $\mathrm{IH}$ admitted in General Surgical Unit of Al-Imamein Al-kadhimein 
Medical City from the $1^{\text {st }}$ of January 2013 to the $1^{\text {st }}$ of February 2015. It includes all types of ventral hernias.

The exclusion criteria were:

- Very large IH with defect more than $10 \mathrm{~cm}$ and difficult achievement of sublay mesh repair in whom peritoneal layer was difficult to be kept or repaired below the mesh.

- Those with emergency surgery.

- Patients lack follow up.

In our study 21 cases of $\mathrm{IH}$ were managed by sublay mesh repair and 42 cases of $\mathrm{IH}$ were managed by onlay mesh repair. Observation in both groups were made with regards to duration and ease of operation, placement and duration of drainage, wound complications, hospital stay, and recurrence. The follow up extended over one year postoperatively with 23 months visit intervals.

Procedure (sublay repair) began with excision of the old scar the hernial sac was dissected to expose the edge of the defect. Here, mesh (Polypropylene) was placed broadly under the defect in the retro muscular layer of the abdominal wall. The mesh extended well beyond the under edges of the defect (about at least 4-5 cm). The center of the mesh was marked by stitch to avoid misalignment of the mesh and the mesh was fixed to the peritoneum by multiple stitches. Organs within the abdomen are protected from injury by the mesh by a peritoneum. Adhesions to intestine are there by avoided. The edge of sheath approximated over the mesh by non-absorbable nylon suture. Suction drains, were placed for all cases for 3-5 days.

In onlay repair, the mesh was placed over the sheath of muscle after approximation the edges of sheath. Dissection of subcutaneous fat from fascia for about 4-5 cm around the defect. Mesh was fixed to the rectus sheath by multiple interrupted sutures and Redivec suction drains, were placed for all cases.

All operations were carried out under general anesthesia with antibiotic prophylaxis of $3^{\text {rd }}$ generation cephalosporin; ceftriaxone, 1 gram daily for initial 2-3 days.

The patients divided into 2 groups. Sublay group include 21 patients and onlay group with 42 patients with comparable medical characteristics.

Postoperative follow up done regularly weekly and by phone communication. Monitoring wound healing, infection, seroma and recurrence. follow up continued for 6 months Data were analyzed using statistical package for social sciences (SPSS) 18.0 software with, Fisher's exact test as appropriate; $p<0.05$ was considered to be statistically significant.

\section{Results}

A total of 63 cases of IH were managed by sublay mesh and onlay mesh repair. Youngest patient was 21-year-old and oldest patient was 69-yearold, mean age of the patients was 46 year. The majority of the patients were female 36 patients which represents $57.14 \%$ and male patients were 27 patients which represents $42.85 \%$. Majority of patients were old age between (5160) were 21 patients which represents $33.33 \%$ of whole patients as shown in table (1).

Table (2) shows the original operations for patients with incisional hernia, where the explorative laparotomy was the most common $(44.44 \%)$, followed by surgeries related to bowel $(28.57 \%)$, and gynecological surgeries formed only (15.87\%).

The main previous incision for $\mathrm{IH}$ of patients involved in this study which shown in table (3) was midline incision (68.25\%), while Pffennenstiel incision was less common $(15.87 \%)$ and Kocher incision was much less common (7.93\%). 
Table 1. Age and gender distribution

\begin{tabular}{ccccc}
\hline Age $(\mathbf{y r})$ & $\begin{array}{c}\text { Male } \\
\mathbf{n = 2 7}\end{array}$ & $\begin{array}{c}\text { Female } \\
\mathbf{n = 3 6}\end{array}$ & Total & Percentage \\
\hline $20-30$ & 3 & 4 & 7 & $11.11 \%$ \\
$31-40$ & 5 & 5 & 10 & $15.87 \%$ \\
$41-50$ & 6 & 7 & 13 & $20.63 \%$ \\
$51-60$ & 9 & 12 & 21 & $33.33 \%$ \\
$61-70$ & 4 & 8 & 12 & $19.04 \%$ \\
\hline
\end{tabular}

Table 2. Original operations for patients with incisional hernia

\begin{tabular}{ccc}
\hline Type of surgery & Number & Percentage \\
\hline Explorative laparotomy & 28 & $44.44 \%$ \\
Bowel related & 18 & $28.57 \%$ \\
Gynecological & 10 & $15.87 \%$ \\
Hepatobiliary & 5 & $7.93 \%$ \\
Other & 2 & $3.17 \%$ \\
\hline
\end{tabular}

Table 3. Types of previous incision

\begin{tabular}{ccc}
\hline Type of incision & Number of patients & Percentage \\
\hline Midline incision & 43 & $68.25 \%$ \\
Pffennenstiel incision & 10 & $15.87 \%$ \\
Kocher incision & 5 & $7.93 \%$ \\
Para median incision & 3 & $4.76 \%$ \\
Grid iron \& lumber incision & 2 & $3.17 \%$ \\
\hline
\end{tabular}

The mean time for surgery in sublay group was 92 minutes (65-120) compared to 70 minutes (50-90) in onlay group for $\mathrm{IH}$.

Suction drain was used in all cases of $\mathrm{IH}$ repair in sublay group drain was removed after 3-5 days of operation.

In onlay group drain was removed in 4-8 days' postoperatively when stop draining except one patient with large $\mathrm{IH}$ drain was removed in $14^{\text {th }}$ day post operatively.

Regarding postoperative complications, were comparable in both groups; in sublay group Seroma formation was one patient (4.76\%). Wound infection was one patient (4.76\%). No septic mesh was removed in the series. In onlay group seroma formation was 9 patients (21.42\%) most of seroma occur in large incisional hernias repair, wound infection was 2 patients $(4.76 \%)$ and in one patient partial disintegrated (septic) mesh was removed.

Regarding recurrence in one year follow up in sublay was $0 \%$, in onlay recurrence rate was 2 patients (4.76\%).

Wound edge necrosis occurs in one case of onlay repair which was managed by excision of necrotic edge \& primary suturing and no case of flap edge necrosis occur in sublay group. as shown in table (4). 
Table 4. Postoperative complications

\begin{tabular}{cccc}
\hline $\begin{array}{c}\text { Postoperative } \\
\text { complication }\end{array}$ & $\begin{array}{c}\text { Sublay group } \\
\mathbf{n = 2 1}\end{array}$ & $\begin{array}{c}\text { Onlay group } \\
\mathbf{n = 4 2}\end{array}$ & $\begin{array}{c}\mathbf{P} \\
\text { value }\end{array}$ \\
\hline Seroma & $1(4.76 \%)$ & $9(21.42 \%)$ & 0.1442 \\
Wound infection & $1(4.76 \%)$ & $2(4.76 \%$ & 1.000 \\
Mesh removal & $0(0 \%)$ & $1(2.38 \%)$ & 1.000 \\
Recurrence & $0(0 \%)$ & $2(4.76 \%)$ & 0.5484 \\
Flap necrosis & $0(0 \%)$ & $1(2.38 \%)$ & 1.000 \\
\hline
\end{tabular}

The overall $p$ value of complications $=0.7527$

\section{Discussion}

Ventral hernia in the anterior abdominal wall includes both spontaneous and most commonly IH after an abdominal operation.

Hernia recurrence is distressing to patients and embarrassing to surgeons where $\mathrm{IH}$ has recurrence rate of up to $30-50 \%{ }^{(20)}$.

The main issue is increased risk of infection with the placement of a foreign body in the form of a mesh.

The incidence of $\mathrm{IH}$ is highest in the $5^{\text {th }}$ and $6^{\text {th }}$ decades of life with a female preponderance. The high female preponderance can be attributed to the majority of index operations being gynecological operations with old mid line or Pfannenstiel incision and atrophied lax rectus sheath. This compares favorably with our results, where most of the patients were females.

Some studies (Table 5) suggest that the use of the sublay technique as a treatment option for incisional hernia appears to be less complicated than the onlay technique ${ }^{(19,21)}$.

Kharde et al. (19) in their study noted that the operative time for sublay mesh repair ( $77.8 \mathrm{~min}$ ) was more than that required for onlay mesh repair (69.8 $\mathrm{min})$. In Saber et al. study ${ }^{(20)}$, the operative time for sublay repair (100 min) where as in onlay repair was (67.5 $\mathrm{min})$. In our study, the mean operative time was higher in onlay (70 $\mathrm{min}$ ) as compared to sublay (92 $\mathrm{min}$ ). Kharde et al. ${ }^{(19)}$ noted seroma in $16 \%$ of the cases managed by onlay mesh repair and $12 \%$ by sublay mesh repair. However, Saber et al. (20) found $6 \%$ seroma rate for onlay and $2 \%$ for sublay mesh repair. In the present study, seroma was a complication that was noted in onlay had $21.42 \%$ and sublay had $4.76 \%$ incidence of seroma.

In our study, wound infection was noted in two cases of onlay, where the mesh got infected and had to be partly removed in one case. In sublay, there was one case of wound infection and no incidence of mesh getting infected. Saber et al. (20) in their study also found that rate of infection was $8 \%$ in patients treated with onlay mesh repair and those treated with sublay mesh repair was $4 \%$. In Kharde et al. ${ }^{(19)}$ the incidence for wound infection were $4 \%$ and $0 \%$ for onlay and sublay repair respectively.

A recurrence rate of $4.76 \%$ was observed in onlay, whereas sublay showed $0 \%$ recurrence rate, Saber et al. ${ }^{20)}$ found $8 \%$ recurrence rate for onlay and $3 \%$ for sublay mesh repair. In Kharde et al., his study noted $4 \%$ recurrence rate for onlay mesh repair of incisional hernias and $0 \%$ for sublay mesh repair ${ }^{(19)}$.

The overall $p$-value as a statistical analysis of our study was not significant however on practical point of view it was significant, in particular the seroma and recurrence rates shown in table (4), this statistical insignificance can be attributed to limited number of patients in our study compared to significant result obtained by meta-analysis study ${ }^{(22) .}$ 
Table 5. Comparison of current study with other studies

\begin{tabular}{ccccccc}
\hline & \multicolumn{2}{c}{ Kharde et al. (19) } & \multicolumn{2}{c}{ Saber et al. (20) } & \multicolumn{2}{c}{ Current study } \\
& Onlay & Sublay & Onlay & Sublay & Onlay & Sublay \\
\hline No. of patient & 25 & 25 & 100 & 100 & 42 & 21 \\
Time of operation (min) & 69.8 & 77.8 & 67.5 & 100 & 70 & 92 \\
Seroma & $16 \%$ & $12 \%$ & $6.0 \%$ & $2.0 \%$ & $21.4 \%$ & $4.76 \%$ \\
Wound infection & $4.0 \%$ & $0.0 \%$ & $8.0 \%$ & $4.0 \%$ & $4.76 \%$ & $4.76 \%$ \\
Mesh removal & $4.0 \%$ & $0.0 \%$ & $0.0 \%$ & $0.0 \%$ & $2.38 \%$ & $0.0 \%$ \\
Recurrence & $4.0 \%$ & $0.0 \%$ & $8.0 \%$ & $3.0 \%$ & $4.76 \%$ & $0.0 \%$ \\
\hline
\end{tabular}

In conclusion, although sublay mesh is a more time consuming and technically more difficult, however, it carries low recurrence rate and few post-operative wound complications.

The authors of current study recommended to adopt the sublay mesh repair of $\mathrm{IH}$ as far as it possible as it associated with a least recurrence rate and post-operative complications. Also to increase the sample of the study to build our experience about the surgery.

\section{Acknowledgement}

Great thank to medical staff of General Surgical Unit of Al-Imamein Al-kadhmein Medical City.

\section{Author contribution}

Both Dr. Hasan and Dr. Al-Helfy participated in study design, performing surgeries, follow up of patients, data interpretation and manuscript organization and editing. Dr. Jabur: final revision and editing of the paper.

\section{Conflict of interest}

Authors declare no conflict of interest.

\section{Funding}

Self-funding.

\section{References}

1. Vincent PJ, Singh Y. Modern management of inguinal hernia. Med J Armed Forces India. 2000; 56(4): 323-7. doi: 10.1016/S0377-1237(17)30220-4.

2. Kingsnorth $A$, LeBlanc $K$. Hernias: inguinal and incisional. Lancet. 2003; 362(9395): 1561-71. doi: 10.1016/S0140-6736(03)14746-0.

3. Ahmad M, Niaz WA, Hussain A, et al. Polypropylene mesh repair of incisional hernia. J Coll Physicians Surg Pak. 2003; 13(8): 440-2.
4. Bucknall TE, Cox PJ, Ellis H. Burst abdomen and incisional hernia: a prospective study of 1129 major laparotomies. Br Med J (Clin Res Ed). 1982; 284(6320): 931-3. doi: 10.1136/bmj.284.6320.931.

5. Bauer JJ, Harris MT, Gorfine SR, et al. Rives-Stoppa procedure for repair of large incisional hernias: experience with 57 patients. Hernia. 2002; 6(3): 1203. doi: 10.1007/s10029-002-0071-3.

6. Ahmed D, Khan MJ. Use of mesh in the management of recurrent incisional hernias. Pak J Surg. 1995; 11: 101-2.

7. Malangoni MA, Rosen MJ: Hernias. In: Townsend CM Jr., Beauchamp RD, Evers BM, et al (eds). Sabiston textbook of surgery: the biological basis of modern surgical practice, $19^{\text {th }}$ ed. Philadelphia (PA):Elsevier Saunders; 2012. p. 1133.

8. Nixon SJ, Tulloh B. Abdominal wall hernia and umbilicus. In: Williams NS, Bulstrode CJK, O'Connell PR (eds). Baily and Love's Short practice of surgery. $26^{\text {th }}$ ed. Boca Raton, FL: CRC Press; 2013. p. 948-70.

9. Wagner JP, Brunicardi FC, Amid PK, et al. Inguinal hernia. In: Brunicardi FC, Andersen DA, Billiar TR, et al (eds). Schwartz's principle of surgery, $10^{\text {th }} \mathrm{ed}$. McGraw-Hill Education. 2015. p. 1495.

10. Stoppa RE. The treatment of complicated groin and incisional hernias. World J Surg. 1989; 13(5): 545-54. doi: 10.1007/BF01658869.

11. Rives J. Major incisional hernia. In: chewal JP (ed) Surgery of the abdominal wall. Paris: Springer; 2000. p. 116-44.

12. Wantz GE. Incisional hernioplasty with Mersilene. Surg Gynecol Obstet. 1991; 172(2): 129-37.

13. Berry MF, Paisley S, Low DW, et al. Repair of large complex recurrent incisional hernias with retromuscular mesh and panniculectomy. Am J Surg. 2007; 194(2): 199-204. doi: 10.1016/j.amjsurg.2006.10.031.

14. Iqbal CW, Pham TH, Joseph $A$, et al. Long-term outcome of 254 complex incisional hernia repairs using the modified Rives-Stoppa technique. World J Surg. 2007; 31(12): 2398-404. doi: 10.1007/s00268007-9260-7.

15. Martín-Duce A, Noguerales F, Villeta $R$, et al. Modifications to Rives technique for midline incisional 
hernia repair. Hernia. 2001; 5(2): 70-2. doi: $10.1007 / \mathrm{s} 100290100010$.

16. Langer C, Schaper A, Liersch T, et al. Prognosis factors in incisional hernia surgery: 25 years of experience. Hernia. 2005; 9(1): 16-21. doi: 10.1007/s10029-0040265-y.

17.Zollinger RM Jr., Zollinger RM Sr. Zollinger's Atlas of surgical operations. $8^{\text {th }}$ ed. McGraw Hill publications. 2003. p. 406-9.

18. Korenkov M, Sauerland S, Arndt M, et al. Randomized clinical trial of suture repair, polypropylene mesh or autodermal hernioplasty for incisional hernia. $\mathrm{Br} \mathrm{J}$ Surg. 2002; 89(1): 50-6. doi: 10.1046/j.00071323.2001.01974.x.

19. Kharde K, Dogra BB, Panchabhai S, et al. A comparative study of onlay and retrorectus mesh placement in incisional hernia repair. Med J DY Patil
Univ. 2013; 6(3): 258-62. doi: 10.4103/09752870.114650

20. Saber A, Bayumi EK. Onlay versus sublay mesh repair for ventral hernia. J Surg. 2016; 4(1-1): 1-4.doi: 10.11648/j.js.s.2016040101.11.

21. Timmermans L, de Goede B, van Dijk SM, et al. Metaanalysis of sublay versus onlay mesh repair in incisional hernia surgery. Am J Surg. 2014; 207(6): 9808. doi: 10.1016/j.amjsurg.2013.08.030.

\section{Correspondence to Dr.Yasir A.Hasan \\ E-mail: yasirzwain@gmail.com \\ Received Oct. $7^{\text {th }} 2019$ \\ Accepted Sep. $10^{\text {th }} 2020$}

